ARTICLE

Received 24 Jun 2016 | Accepted 4 Oct 2016 | Published 29 Nov 2016

DOl: $10.1057 /$ palcomms.2016.80

OPEN

\title{
The EU and the international sanctions against Iran: European and Iranian foreign and security policy interests, and a changing Middle East
}

\author{
Peter Seeberg ${ }^{1}$
}

\begin{abstract}
In July 2015 an agreement on the so-called Joint Comprehensive Plan of Action regarding Iran's nuclear program was announced between Iran and the permanent members of the UNSC, Germany and the EU. The Iranian decision to comply with the results of the negotiations attracted much focus, both at the policy level and in scholarly debates. However, the foreign and security policy interests and possibilities of Iran in the MENA region have not been discussed very intensively, nor has there been much attention paid to how the international actors and in particular the EU were able to influence the Iranian policies and decisions. This article seeks to take up this challenge: firstly by analyzing to what degree the sanctions influenced the Iranian decisions on the nuclear issue; and secondly, by discussing how the sanctions regime affected the relations between Iran and the international actors, with a specific focus on the EU and the ability of Iran to pursue its foreign policy interests in the Levant and the Gulf. This article is published as part of a collection on analysing security complexes in a changing Middle East.
\end{abstract}

\footnotetext{
${ }^{1}$ Syddansk Universitet, Odense M, Denmark Correspondence: (e-mail: seeberg@sdu.dk)
} 


\section{Introduction}

- his article analyses the specific role of the EU in connection with the negotiations with and sanctions against the Islamic Republic of Iran in the context of a changing Middle East since the Arab uprisings, where the problematic developments in several Arab states (Egypt, Libya, Syria, Yemen...) resulted in a more fragile and destabilized political situation in the Middle East region. The role of the EU is analysed in the context of how international actors sought to influence Iran in an attempt to affect the security environment of which Iran is a part and thereby the Iranian foreign and security policy. To put pressure on the regime in Teheran a comprehensive sanctions regime was imposed on Iran and played a role in defining the foreign and security policy conditions for the Iranian state in two different geostrategic contexts.

First, Iran is pursuing its interests in the unstable Levant and is, in connection with that, affected by the ongoing war in Syria and the significant position of new non-state actors, not least the Islamic State (IS) or Daesh. Secondly, Iran plays a significant role in the Gulf, where it takes part in a triangular rivalry with Iraq and the Gulf Cooperation Council (GCC) states, in particular Saudi Arabia. Thus, focusing on Iran in the Middle East in the context of international security structures involves (at least) two security subcomplexes, the Levant and the Gulf (Buzan and Wæver, 2003: 7). In the Levant, Iran has traditionally been maintaining a significant position via its alliance with Syria, Hezbollah and Hamas. This alliance, however, is not as strong as it used to be. The weakening of Iran's traditional ally, Syria, as a result of the Syrian civil war, represents a setback for Teheran, as shown by Khatib (2015). Added to that the Hezbollah, taking part in the war in Syria in support of the regime in Damascus, experiences a relative weakening as a result of the emergence of IS on the political and military scene in (Iraq and) Syria. Finally Hamas has broken its close relationship with the Syrian regime.

Still, Iran plays an important role as an external actor in the eastern Mediterranean. In the Gulf the structure of the regional balance of power drives competition between Iran and its Arab neighbours, in particular the GCC countries, and in connection with that, the nuclear issue frequently has been emphasized by the GCC as a source of instability. Iran was subject to severe international sanctions; for years the UN, the United States and the EU contributed to a comprehensive sanctions regime aimed at influencing the Islamic Republic, first of all with the ambition of being able to control the controversial Iranian nuclear program (Dreyer and Luengo-Cabrera 2015; Katzman, 2015). ${ }^{1}$

It is the idea of this article to analyse foreign and security policy challenges related to European-Iranian relations with a specific focus on how and to what degree the sanctions have played a role in connection with the policies of Iran in the two security subcomplexes in the Levant and the Gulf. The article argues that there is a complex and ambiguous interrelatedness between the sanctions imposed on Iran and the development over recent years of the Levant and Gulf security subsystems and thereby in a broader Middle Eastern perspective. The political realities for Iran might, as claimed by Thomas Juneau, to some degree live up to the label "strategic loneliness", (Juneau, 2014) but when the different aspects related to the sanctions are included in the analysis, the perspective changes and makes it clear that the recent political conditions for the Islamic Republic are somewhat ambiguous and furthermore seem to indicate that the efficiency of the sanctions to some degree can be questioned.

Internally in Iran there is hardly any doubt that the right to develop nuclear power facilities enjoys widespread support among most Iranians and that the same goes for the "official" criticism of the imposed sanctions. And initially Iran seemed to be able, by diversifying its international linkages, to some extent to counteract the effect of the international sanctions, thus making it easier for Iran to pursue its foreign policy interests. Added to that, one of the largest sanctions-sending entities, the $\mathrm{EU}$, experienced a lack of consensus among its member states concerning the sanctions (Alcaro and Tabrizi, 2014; Onderco, 2015). There were several examples of this, and they indicate a lack of coherence attached to the EU as a foreign-policy actor.

The relatively isolated political situation for Iran, the effect (despite counteracting manoeuvres) of the sanctions, and the deteriorating strength of its alliances in the Arab region altogether point at a decline of Iranian influence in the two heterogeneous security subcomplexes, or to speak with Buzan et al., miniature anarchies analysed in this article (Buzan et al., 1998). It is the ambition in the first place to analyse how and to what degree the sanctions against Iran were able to influence the Iranian decisions on the nuclear issue. Second, it is the intention to discuss how the imposing of the sanctions regime affected the specific European-Iranian foreign and security policy relations. And third, the article will examine if and in what ways the sanctions have played a role in influencing Iranian ability to pursue its policies in the two mentioned regional subcomplexes mentioned above: the Levant and the Gulf.

\section{Analytical framework: regional security complexes, recombinant authoritarianism and the effect of sanctions}

The conceptual understanding of a regional security complex within the context of the Copenhagen School is associated with this definition: "a set of units whose major processes of securitization, desecuritization, or both are so interlinked that their security problems cannot reasonably be analysed or resolved apart from one another". (Buzan and Wæver, 2003: 44) This definition emphasizes the significance of the state as actor and the notion of securitization/desecuritization in state relations. Furthermore, the military-political focus of the definition underlines that the securitization and desecuritization processes express themselves in regional clusters-in the context of the Gulf what Payam Mohseni calls "the Iran-Saudi cold war" (Mohseni et al., 2015). The permanent tension between Iran and Saudi Arabia (and the other GCC states) is a good example of this, and it is obvious that the rivalry unfolds itself on many different stages, where some deal with internal affairs in a specific state (as in the case of Iranian support for Shia Muslim interests in Bahrain), some are regional (regarding Iraq, where the common IranSaudi interest in a weak Iraq interferes with the Iranian interest in influencing the Shia-majority in Iraq), and some are extraregional (as in Afghanistan, where Saudi Arabia and Iran have supported different factions in the internal wars there). The rivalry between Saudi Arabia and Iran, aggravating sectarianism across the Middle East region, is also emphasized in the Global Strategy document of 30 June 2015, launched by the EU High Representative Federica Mogherini: "The European Union in a changing global environment", where the challenges for the EU external instruments are underlined (Mogherini, 2015).

The Gulf Wars have, as implied by Buzan and Wæver, led to a change in the status of the GCC states, where they have to some degree reached a position like being protectorates of the West and in particular the US (Buzan and Wæver, 2003: 205). Thus, the relative weakening of Iraq as a result of the Western intervention has in principle strengthened the position of the GCC states $v i s-\grave{a}$-vis Iran. On the other hand, Iran (certainly without being an ally of the US) has also gained from the weakening of Iraq. This paradox emphasizes the complexity and dynamic character of the Gulf regional security subcomplex. An important discussion within research deals with if Iran to some degree has been able to 
counteract the effect of the international sanctions by diversifying its external relations (Kozhanov, 2011).

In an analysis of Iran and Syria, Steven Heydemann and Reinoud Leenders have discussed this element in connection with an attempt to elaborate the paradigm of authoritarian resilience, where they suggest focusing on the adaptive capacities of regimes being faced with changing political and/or economic conditions. They have developed the notion of recombinant authoritarianism, being defined as "systems of rule that possess the capacity to reorder and reconfigure instruments and strategies of governance, to reshape and recombine existing institutional, discursive, and regulatory arrangements to create recognizable but nonetheless distinctive solutions to shifting configurations of challenges". (Heydemann and Leenders, 2011: 7; Heydemann and Leenders, 2013) If the pressure first of all from the West is seen as an example of this mechanism, then the ability to fill the vacuum (lack of foreign trade) by looking elsewhere (to Russia, China and so on) represents an expression of recombinant authoritarianism (Ehteshami et al., 2013).

The theoretical literature, discussing if, when, and why sanctions work, has a relatively long history and reveals significant disagreements regarding to what degree sanctions are considered efficient (Drezner, 2000; Chesterman and Pouligny, 2003). The classical debate focuses mostly on economic sanctions and deals with different kinds of boycotts, embargos, or financial sanctions imposed on, for instance, Rhodesia and South Africa (Portela, 2010: 11ff). The complexity of the sanctions phenomenon is an important part of the reason why scholarly research contests to what degree the increasing economic consequences of economic sanctions for the targeted state will tend to lead to a higher level of efficiency of the sanctions (Elliott, 1998; Pape, 1998; Baldwin, 1999/2000). Briefly, the argument is that, in order to be considered efficient, economic impact will have to be followed by political decisions of complying with the sanctions. The targeted regime might have an interest in rejecting foreign interference in its internal affairs with the ambition of increasing internal cohesion in a given society-as when faced with international sanctions the Iranian Supreme Leader Ayatollah Khomeini, argued that Iran was pursuing a policy of a "resistance economy" (Bazoobandi, 2015: 64). This article does not discuss in detail the unhealthy internal economic environment in Iran due to long-standing structural challenges or to what degree the lack of ability to deal with them have added to convincing the Iranian regime of the necessity of opening up to the international community.

Later on when targeted sanctions were invented-and sometimes inflicted on so-called pariah states-they were obviously also exposed to scholarly discussion and assessment (Thomas, 2013). As described by Portela (2010: 19), the EU established a practice of imposing sanctions from the early 1980s, and from the early 1990s targeted sanctions on behalf of the EU were applied. In the case of Iran, sanctions were not imposed before the UN implemented their sanctions, and then a variety of EU sanctions were imposed consisting of travel bans, arms embargos, freezing of assets and commodity boycotts (Giumelli and Ivan, 2013). It is therefore obvious that the analysis is becoming more complex and that it can be difficult in the given case to determine what type of sanctions is the more efficient. This article assumes that the reason why the sanctions imposed on Iran demonstrate a relatively high degree of efficiency can be explained by analysing a combination of external and internal dimensions of the political and economic conditions for Iran in the given context. In other words, this article hypothesizes that (1) the high level of harm inflicted on the Iranian economy by external sanctions contributed to persuading the regime to come to terms with the sanctions regime; that (2) the specific role of the EU regarding the negotiations with and sanctions against Iran and in connection with that the relatively high degree of international consensus and cooperation between the sanctioning states added to the efficiency of the sanctioning regime; and that (3) the sanctions played a role in determining the Iranian ability to pursue its policies in the Levant and the Gulf security subcomplexes.

\section{International sanctions with a focus on EU measures} International sanctions: The UN and the United States. The sanctions on Iran are without doubt among the toughest the world community has imposed on any country within the recent decades. Since 2010, the sanctions tended to focus in particular on the nuclear issue, but most sanctions had multiple objectives, addressing different perceived threats (Katzman, 2015). The UN sanctions went back to 2006, starting with UNSC Resolution 1696 , "noting that ... the IAEA is unable to conclude that there are no undeclared nuclear materials or activities in Iran ... [and] expresses its intention ... to persuade Iran to comply with this resolution" (UN, 2006). The following UNSC resolutions, adopted in 2006 and 2007, focused on the nuclear issue as well and added measures preventing supplies to Iran of nuclear-related materials and technology. The sanctions aimed at affecting persons involved in the nuclear program or in the ballistic missile program (UNSC Resolution 1737) and also included an arms embargo on Iran (Res. 1747). In 2008, the sanctions involving freezing of assets were extended, and it was also proposed to monitor the activities of Iranian banks (Res. 1803). Furthermore, it was decided to inspect the cargo to and from Iran of aircraft and vessels owned or operated by Iran Air Cargo and Islamic Republic of Iran Shipping Line if, as it said, "reasonable grounds existed to believe that the aircraft or vessel was transporting prohibited goods." (UN, 2008) Also in 2008, a resolution (1835) was adopted confirming the four former resolutions. UNSC Resolution 1929 of 2010 added impetus to these types of sanctions, and with Resolutions 1984, 2049, 2105 and 2159, the mandate of the panel of experts formed by the UN to monitor the sanctions against Iran over its nuclear program was extended for the years 2011, 2012, 2013 and 2014. Finally, the UNSC adopted Resolution 2231 of July 2015, which enshrined the JCPOA agreed upon in Vienna (UN, 2015b).

In connection with the following discussions in the $\mathrm{UN}$, and on behalf of the US Government, the US Permanent Representative to the UN, Samantha Power, expressed satisfaction with the achievements in Vienna, but at the same time emphasized that the US would "maintain [its] own sanctions related to Iran's support for terrorism, its ballistic missiles program and its human rights violations" (UN, 2015a). The United States has sanctioned Iran for decades, starting after the Iranian revolution in 19781979, when the United States, as an official response to the occupation of the US Embassy in Teheran and the hostage taking, froze Iranian assets. According to Pollack (2004: 164), the Iranians, in order to deny leverage to the US, were about to start withdrawing all of their assets from US Banks when US President Jimmy Carter ordered the freeze of deposits, estimated at around $\$ 12$ billion. Furthermore, all trade with Iran was cut off except exports of humanitarian goods such as food and medicine. The policy of sanctions later-under US President Bill Clintonbecame a central part of the Dual Containment policy against Iran and Iraq (Pollack, 2004: 261). The United States increased the sanctions in the 1980s and also in 1990s, mainly with the purpose of compelling Iran to give up its support of alleged terrorist activities and to limit Iranian influence on the security subcomplexes of the Middle East (Katzman, 2015: 1). From the mid-2000s, the United States sanctions focused on pressuring the Iranians not to change the character of the Iranian nuclear 
program, so that it continued only to deal with civilian use. The US interests are obviously related both to their own overall strategic interests, but also to those of their allies and here it is important to differentiate between Saudi and Israeli interests vis$\grave{a}$-vis Iran. The Saudi interests focus on potential Iranian influence in the Gulf, including the sectarian dimension and the question of internal stability in Saudi-Arabia and the GCC-states in general. The Israeli interests deal with Iranian influence in the Levant and the potential strategic changes related to possible changes of the Israeli threat environment (Albright et al., 2014). The sanctions were stepped up, especially from 2010 , to intensify the pressure on the regime in Teheran. An interesting expression of this could be seen when in January 2015 the US Senate Banking Committee attempted to advance a bill threatening additional sanctions in case the international negotiators should fail to reach a final agreement by mid-2015.

Phases of the EU's sanctions from negotiated solutions to postagreement. The EU sanctions against Iran followed a different pattern than the US sanctions. The process that led to the Vienna talks originated in a tripartite initiative by France, Germany and the United Kingdom, where the three dominant EU countries succeeded in persuading the Iranians to accept being part of negotiations taking their point of departure in international concerns that the Iranian nuclear program might have a military dimension (Alcaro and Tabrizi, 2014). This followed a relatively long history of mutual mistrust, in which the EU and Iran had difficulties in reaching common grounds for contacts, let alone negotiations, but where EU sanctions were "largely limited to enforcing targeted sanctions imposed by the United Nations from 2006" (Patterson, 2013). In 2009, some individual EU member states, like France and the United Kingdom, suggested significant economic sanctions against Iran, and this revealed a lack of consensus within the EU (Patterson, 2013: 135). Added to that, as described by Michal Onderco, the lack of agreement over time expressed itself in different patterns. The United Kingdom was the first EU country to argue that sanctions should be adopted for Iran, when a critical Iran dossier reached the UNSC. France did not share this view right away. This became a reality after the election of President Nicolas Sarkozy, while in the meantime Germany remained isolated in a relatively soft approach, where they argued that Iran should be allowed specific limited enrichment activities (Onderco, 2015: 59). Summing up, the policies related to decisions on sanctioning Iran have been somewhat incoherent, and it took some time after the establishment of the EEAS, following the adoption of the Lisbon Treaty, before the EU was able to enter into negotiations with Iran. It is relevant briefly to describe the phases leading up to the establishment of the sanctions regime and the history of the sanctions until the agreement was reached in 2015 .

The EU's early soft power strategy. In a first phase-going back to before the turn of the century and lasting until the middle of the following decade, before the start of the UN sanctions began being implemented and while the United States pursued the Dual Containment policy-the EU attempted to influence the Iranian regime via a soft-power strategy, going for negotiated solutions. The EU seemed to believe, probably partly as a result of a relatively positive assessment of the then "reform-President" Mohammad Khatami, that it would be possible to win over Iran for talks aiming at diplomatic progress-in the long run "bringing civilizations together", as was the narrative of the speeches given by the Iranian President among others in Paris and Rome in 1999 (Mirbagheri, 2007). A dimension of the soft power strategy was local cooperation by EU diplomats with representatives from Iran or from its "allies", for instance Hezbollah in Lebanon. ${ }^{2}$

Initially the so-called E3-France, Germany and the United Kingdom-took the lead on behalf of the EU. They brought forward incentives related to civilian use of nuclear power for Iran, for instance by offering technical support. They also offered to strengthen commercial ties between the EU and Iran, including in the energy sector and also to work for Iran's accession to the WTO (Kienzle, 2012). The EU presented an early breakthrough in the negotiations when in 2004 it succeeded in landing the Paris Agreement, where Iran "consented to freeze enrichment and to sign the IAEA Additional Protocol in exchange for trade and technology benefits from the EU." (Portela, 2015) It didn't take long, however, before the positive tendencies were reversed.

New Iranian leadership and the EU response. With the election of Mahmoud Ahmadinejad as President of Iran in 2005 Iranian policies changed, starting with the announcement that they would start enriching uranium at 20 percent. The differences between two presidents, as remarkable as they may be, do not explain everything, but it seems reasonable to speak of a second phase in European-Iranian relations lasting from 2006 to 2010. The period started with the newly appointed President Ahmadinejad announcing that Iran would start enriching its plutonium and ended with doing exactly that, thus presenting the international community with a new reality. This convinced the EU to impose additional sanctions to the ones already adopted from 2006 following the UNSC sanctions.

Five years later, this was actually being carried out, which made the EU move closer to the United States in its policies toward Iran (Portela, 2015: 190-191). Things also changed at the negotiating table, where the non-European members of the UNSC, the United States, Russia and China, accepted being represented by the EU High Representative Catherine Ashton.

This model for negotiations presented an indirect conflict of interest. On one side, the pressure on Iran became stronger through the more massive leverage provided by the consensus among the European and non-European permanent members of the UNSC. However, on the other side, the different conditions for the EU and the United States in their strategic position $v i s$-à-vis Iran were able to lead to a weakening of the alliance against Iran. One example is the oil issue, where the United States -in contrast to the EU-had no problem with imposing an oil embargo on Iran (Van de Graaf 2013). Furthermore the new situation tended to reopen divisions among the EU member states (Patterson, 2013). According to Patterson, of the "anti-sanctions camp" countries within the EU, consisting of Greece, Cyprus, Ireland, Portugal, Spain and Sweden, all except for Sweden would be hit by an oil embargo against Iran (Patterson, 2013: 142).

EU adopts "autonomous" sanctions. From 2010, as analysed by Erica Moret, the EU, which formerly had been "reluctant to align EU policy on Iran with the stance of the US government whose sanctions against the country are particularly extensive", (Moret, 2015) changed its policies and sharpened the sanctions in a third phase, where so-called "autonomous" sanctions were adopted by the EU (Bazoobandi, 2015). The homepage of the EEAS presented a 140-page-long list of the 35 states under sanctions by the EU and the restrictive measures being enforced against them. The list showing the sanctions against Iran was 17 pages long and described a significant number of sanctions, all of which were the result of EU Council Decisions from 2010 to 2015 (EEAS, 2015). The sanctions represented a broad spectrum of measures with a focus on violation of human rights, different types of embargos, restrictions related to specific types of production (for instance oil or gas production), or related to 
the nuclear issue. The individual sanctions entailed restrictive measures, as in Council Decision 235 of 14 April 2011, where a specific person, the first one mentioned being Chief of Iran's National Police Esmail Ahmadi-Moqaddam, was allegedly responsible for the fact that "Forces under his command led brutal attacks on peaceful protests, and a violent night time attack on the dormitories of Tehran University on 15 June 2009." (EEAS, 2015: 32) The actual sanction entailed a travel ban which involved all EU member states and the freezing of economic resources belonging to the given person.

Applying the oil embargo. A fourth phase might be identified from 2012, when the oil embargo was implemented. From that time the Iranian economy was more seriously affected by the international sanctions, as demonstrated by Peter Bergeijk (Bergeijk, 2015). In the case of embargos, certain commodities of importance for the Iranian regime were exposed to restrictions. For instance, regarding equipment relevant for telecommunications, Council Decision 168 of 24 March 2012 specified a restriction on: "The sale, supply, transfer or export of equipment or software intended primarily for use in the monitoring or interception by the Iranian regime ... [and] equipment which might be used for internal repression to Iran". In some cases, besides the general embargo, this involved targeted persons who might be directly involved in the use of the mentioned type of equipment for the purpose resulting in the sanction (EEAS, 2015). The same doubling applied to the restrictions related to specific types of production of strategic significance, where the sanctions were intended to influence the given type of production and the persons (owners, leading employees) responsible. Some of the most comprehensive sets of sanction were those related to the nuclear issue. Council Decision 413 of 27 July 2010 and Council Regulation 267 of 24 February 2012 represented this category. Regulation 267 made it clear that sanctions were imposed in relation to "other goods and technology which could contribute to Iran's enrichment-related, reprocessing or heavy-water-related activities, to the development of nuclear weapon delivery systems, or to the pursuit of activities related to other topics about which the International Atomic Energy Agency (IAEA) has expressed concerns" (EEAS, 2015).

The post-agreement phase. It can be argued that 2015 saw the beginning of a fifth phase, which could be termed a postagreement phase. According to the JCPOA of 14 July 2015, a timeframe was agreed upon by the following partners: China, France, Germany, the Russian Federation, the United Kingdom, the United States and Iran-with the goal that "The full implementation of this JCPOA will ensure the exclusively peaceful nature of Iran's nuclear programme" and that "Iran reaffirms that under no circumstance will Iran ever seek, develop or acquire any nuclear weapons." (JCPOA, 2015) In addition to this general statement, a number of detailed provisions were brought forward in the document, listing 17 demands which Iran should live up to when dealing with nuclear issues: enrichment, stockpiles and so on. ${ }^{3}$ On the other side, the sanctioning states promised to change or terminate sanctions imposed on Iran. Furthermore, the document contained an implementation plan, which described how the above-mentioned details should be implemented over the days, weeks and years following the conclusion of the agreement until-ideally speaking-the agreement was fulfilled on both sides of the negotiating table.

\section{The Levant and the Gulf security subcomplexes, and European-Iranian relations}

It is the official Iranian position that it never had plans of exploiting its nuclear resources for military purposes.
Nevertheless the potential threat of Iran being in possession of nuclear weapons was a source of grave concern in both the Levant and the Gulf (Ehteshami et al., 2013). Not least Israel-and in particular the Israeli media-fearing that Iran might intend to use atomic weapons for the purpose of removing the Jewish state from the surface of the earth, argued against Iran being allowed to develop their nuclear program. Israeli Prime Minister Benyamin Netanyahu claimed that Iran was a "wolf in sheep's clothing" and that any deal with Iran would be a historical mistake (Juneau, 2014: 102). Iran, on its part, attempted to become "champion of the Palestinian cause" and sought to encircle Israel through its connections with Syria, Hezbollah and different Palestinian rejectionist groups, in particular Hamas (Juneau, 2014: 98). At the same time, Iran was challenged by what might be considered as the hegemonic power on the Arab side of the Gulf, Saudi Arabia, which at least regarding economic strength gained from the relative weakening of Iran following the pressure over the last years from the international sanctions, and in particular as a result of the oil embargoes.

Since the Iran-Iraq war brought Iran and Syria together in opposition to Saddam Hussein's Iraq, there have been close relations between the two states. The Iranian strategic goal of fighting Israel was shared by Syria, and with strong non-state actors as allies, the goal was pursued by both states. The war in Syria from 2011 tended to weaken the alliance, as the regime in Damascus appeared more and more isolated in the Arab region, supported only wholeheartedly by Hezbollah (Seeberg, 2015). Potentially, the nuclear agreement with Iran of July 2015 might result in a relative weakening of its links to Syria and the Hezbollah, but obviously this seems somewhat speculative. Clearly Hezbollah plays a role in the complex relations between Iran and the West, and the EU has traditionally had major difficulties in dealing with this particular role of Hezbollah (Seeberg, 2009). The EU-knowing the strength of Hezbollah in Lebanon-indirectly attempted to reduce its influence. In July 2013, the EU's foreign ministers agreed to put the armed wing of Hezbollah on its list of terrorist organizations (EurActiv, 2013). This was officially because of an alleged involvement of Hezbollah in a terrorist attack in Burgas, Bulgaria, but there is hardly any doubt that the direct military involvement of the Shiite group in Syria, in support of President Bashar al-Assad, shifted the opinion of several EU politicians. ${ }^{4}$ At the same time, however, it was made clear that the EU would maintain contact with the Hezbollah party, being part of Lebanon's parliament and also an important part of the complicated ethnic-religious realities in Lebanon, with which the EU wanted to stay in contact (Fakhoury, 2014).

Traditionally the United States-Saudi cooperation has been a continuous obstacle for Iran's foreign policy opportunities (Monshipouri and Dorraj, 2013). On the other side, the tight connection between Washington and Riyadh has also been a useful phenomenon for the rhetoric of Iranian outbursts against the Saudis. The discussion in the United States underlines the close alliance between the United States and the GCC states, and only few subscribe to the argument by Waltz (2012)_building on a balance of power logic-that the world could live with Iranian nuclear weapons. Regarding the negotiations leading toward Vienna, Saudi Arabia officially supported them, but in reality the Saudis were highly sceptical about progress in the negotiations. Saudi Arabia feared that a deal might result in a situation where Iran can "maintain a residual nuclear program" (Juneau, 2014: 102). Furthermore, the GCC states fear that the recent balancedue to their massive investments in advanced weapon systems, which Iran cannot match-might be outweighed by Iran's latent nuclear capability, which even in the long run could mean an Iranian nuclear weapon. The United States is obviously not interested in a such a scenario, but has at the same time an 
interest in levelling the rhetoric when it comes to the relation between the United States, its Arab partners and Iran-as expressed in this statement by Barack Obama: "America has to listen to our Sunni Arab allies, but also not fall into the trap of letting them blame every problem on Iran. The citizens of more than a few Arab Gulf states have been big contributors to Sunni jihadist movements that have been equally destabilizing" (Friedman, 2015).

Part of the complexity of the interplay between the regional and international actors has to do with paradoxical commonalities of interests between Iran and the United States in a weakened Iraq. The US-led invasions in Iraq in 1991 and 2003 indirectly strengthened Iran, simply because the Iranians were able to focus less on the security challenges from Iraq and more on the possibilities for advancing Iranian interests in the Levant and the Gulf without being afraid of the rivalry from Iraq. Added to that, the regional security subcomplexes in which Iran is a significant actor are characterized by other forms of interconnectedness, namely in the sense that the development in the Middle East since 2011 with the Arab uprisings led to a restructuring of some stateto-state relations and also to changes within Arab organizations. Attempts from the side of the GCC states to include Jordan (and Morocco) in the GCC "community" can be interpreted as an attempt to stabilize the Levant subcomplex (Helfont and Tally, 2012), suffering from the chaotic situation in Syria, and the threat from emerging IS. It can also be seen as an investment in partners, which can contribute to strengthening the GCC states in their strategic challenges from Iran-both in the Gulf and, via Syria and Hezbollah, in the Levant. As already mentioned, Israel is another actor that establishes a connection between the two subcomplexes, resulting from its tight connections to the United States, its explicit criticism of the Vienna agreement, and challenges from Hezbollah in Lebanon, strongly supported by Iran.

Summing up, the transition since 2011 resulted in a shifting strategic landscape in the Middle East. The European response to the Iranian nuclear proliferation crisis was probably one of the foreign policy areas within which the EU was able to function as a relatively cohesive actor (Portela and Ruffa, 2015). As shown above, this does not mean that the cooperation within the EU was without disagreement, and it should also be mentioned that in connection with some issues reluctance on the part of the EU as a whole could be identified. In other words, as formulated by Alcaro and Tabrizi (2014: 14): "While the Europeans can be credited with some unquestionable achievements, the dispute has also laid bare the limits of European foreign policy".

The limits can be described in different ways related to the EU foreign and security policy interests, primarily focusing on four areas. First: Regarding the economic dimension, the EU had been an important trading partner for decades and obviously there was an interest in protecting and-if possible-expanding the trade relations between Iran and the EU. Second, it was important to continue the non-proliferation regime related to Iran's nuclear program. Third, the European interests focused on keeping an eye on the Iranian influence in the Levant, initially in relation to Lebanon, and later on related to the Syrian crisis from 2011 and onwards. Fourth, the EU had a strategic interest in (contributing to) preventing the rivalries in the Gulf between the GCC states and Iran from escalating. To a certain extent the EU had the necessary tools for pursuing the first two foreign policy goals. Given an internal consensus in applying economic instruments, the EU would be able to affect the Iranian economy. In 2011, as shown by Francesco Giumelli and Paul Ivan, as the EU accounted for almost one third of Iran's export and around 23 percent of its oil export, this meant that together the EU countries were Iran's largest trading partner (Giumelli and Ivan, 2013: 17). Also the EU was able to play a role as part of the control measures built around the Iranian nuclear program. The steps taken by the EU turned out to be efficient in the sense that in 2008 its status as most significant trading partner was exchanged in 2012 for a position as number four (Giumelli and Ivan, 2013: 17). The years after 2012 saw European trade with Iran drop even further (Bergeijk, 2015: 50), and this reality appeared without causing any significant split between the EU member states. Regarding the third and fourth EU foreign policy interests, the EU lacked the necessary means to pursue the goals. In the Gulf in particular, the EU would have to rely on some kind of US interference, especially when it came to the military dimensions of the strategic relations.

In the Levant, Iran's alliance with Syria and Hezbollah has been a source of influence for the regime in Teheran. Nevertheless it would seem likely that the Iranians consider the recent situation in Syria to be an obstacle for improving its relations with the international community. Obviously the Iranian decision to support the Syrian regime as the internal conflict escalated has not been without costs. However, despite the economic reasons for resisting a permanent involvement in the Syrian crisis, as argued by Terrill (2015: 223), “Iran's leadership has remained committed to President Bashar al-Asad's survival due to political and strategic concerns". Beyond the traditional "revolutionary solidarity" between Iran and Syria, these concerns are related to the new significant non-state actors in the Levant, namely the al-Qa ida-affiliated Jahbat al-Nusra and the IS. It is obviously not in the interest of the Iranians to allow a replacement of the Teheran-loyal Ba'athist regime in Damascus with powerful and unpredictable radical movements like IS, fighting for a Sunnibased Caliphate. The emergence of IS on the political-military scene in the Levant has added another commonality of interest to the already existing alliance between Iran and Syria, thereby linking the Levant security subcomplex together with the Gulf subcomplex. An additional point is the paradoxical commonality of interest between Iran, Syria, and the EU as a result of the entrance of IS into the conflict patterns of the Levant. In this context, Iran can offer to use its influence in the Levant, via Syria and Hezbollah, as an asset in negotiations with international actors in the UNSC. By indirectly supporting the international coalition against IS, which includes international actors as well as Arab states, Iran can gain advantages. And, as things have developed in the Levant, the coalition against IS probably prefers not to attempt to remove Assad and thus tends to have fewer objections to Iran's Syria policies than might have been the case a few years ago (Terrill, 2015: 236).

Regarding Iranian-European relations in the Gulf, it is a fact that the EU has limited strategic influence there. The most significant EU influence in the Gulf derives from the economic relations with the GCC states, with which the EU maintains trade and investment cooperation. The financial crisis since 2008-9 has to some degree prevented dynamic cooperation between the Arab Gulf states and the EU, which according to Valentina Kostadinova was expected, from materializing. Still a relatively comprehensive and growing economic exchange is taking place between the EU and the rich Gulf states (Kostadinova, 2013). Iran would like to be part of this trade and investment cooperation, but for years this has been impossible. Obviously a commonality of interests exists within this field. Iran has attempted to replace the Western international actors by establishing economic ties with China, India, Russia and so on, but the strategic interests in being continuously able to import goods and advanced technological equipment from the EU (and the United States) are obviously recognized in Iran. Furthermore bilateral trade agreements with other trading partners have been very difficult to maintain, since the possible partners to the East have also been 
enrolled into the international sanctions against the Iranian nuclear program.

\section{Conclusion}

The mutual interest of the EU and Iran in re-establishing trade relations will probably turn out to be a significant factor for their future cooperation. Beyond the US sanctions this will probably also be the case for US-Iranian trade relations. It seems realistic that a lifting of the oil embargo could play an important role in this context (Tichý and Odintsov, 2016). The rivalry between Iran, Iraq, and Saudi Arabia in the Gulf makes the issue relevant because a very large part of the low-cost production and export of oil and natural gas in the world potentially takes place in the GCC states, Iran, and Iraq (Miller et al., 2015: 12). ${ }^{5}$ Specifically regarding the Arab-Iranian relations it is a highly complex field, and the GCC states do not necessarily have identical interests. Some of the small GCC states might have a long-term interest in cooperating with the Iranians, whereas Saudi Arabia, which already has a deep mistrust of Iran, mainly sees it as a (potentially strong) competitor (Miller et al., 2015: 13).

The Iranian response to the sanctions was very bitter, and, exposed to the relatively high level of international consensus in sanctioning Iran, the Religious Leader Ayatollah Khamenei held speeches referring to international interference in Iranian internal affairs; the speeches containing rhetorical outbursts in which he claimed that if you "show flexibility, arrogant powers will make their threat more serious" (Maloney, 2015: 480). In the coming years, there will be an obvious (and highly interesting) research task related to following a possible rapprochement between Iran and the international sanctioning powers and, as stated by Iana Dreyer, "the degree to which Tehran will abide by the terms of the July 2015 JCPOA will also be crucially influenced by the sanctioning actors' own credibility in rewarding Iranian compliance with concomitant sanctions relief" (Dreyer et al., 2015: 78). As expected there will be some differences between the $\mathrm{EU}$ and the United States in this respect, as a result of the differences in the sanctioning practices both before and after the JCPOA.

It is therefore relevant initially to discuss what lessons can be learned from the period in which the sanctions was imposed. Sanctions are sometimes employed even though their efficiency in the given case might not be evident, simply because the use of force comes at too high a price. Obviously Iran is and has been a difficult opponent to deal with for the international community. As argued by Oskarsson (2012: 98), Iran is a good example of a state where the regime has been able to get around the sanctions and still stay in power. The regime has also been able to manoeuvre for some time to avoid a united front of sanctioning powers, but as the international consensus on sanctioning Iran grew stronger, it decided to accept the conditions imposed by the international sanctioning powers. Iran's foreign policy represents, both before and after the decision of complying with the sanctions regime, an interesting example of "recombinant authoritarianism" and in connection with that the EU played a significant role in maintaining the international sanctions "coalition" (Portela, 2015). The Iranian moderation can have important consequences for its population, as analysed by Mohseni: a de-securitization of Iran's international nuclear file will potentially have significant domestic implications-in particular if it is combined with a successful Western strategy of reintegrating Iran in the global economy (Mohseni et al., 2015: 14)

It seems meaningful to claim that the sanctions influenced the Iranians' decisions on the nuclear issue, leading to the situation where President Hassan Rouhani, representing the Iranian state, accepted the conditions of the JCPOA, thereby laying the foundation for Iran emerging from its "strategic loneliness," as coined by Thomas Juneau. This article has argued that the EU's role as negotiator and mediator, its adoption of the UNSC sanctions, and its own sanctions together point to the conclusion, that the EU (together with the United States) should be considered a significant player in the development leading to the final agreement in Vienna. For almost two decades, the relationship between Iran and the $\mathrm{EU}$ was influenced by the issues related to the Iranian nuclear program. The phases identified in the article underline the development of the specific role of the $\mathrm{EU}-$ also in the construction of the international sanctions regime, which at last seemed to convince Iran to accept the conditions offered in connection with the negotiations. The EU, as argued by Morillas (2015), might be on its way to developing into an important foreign policy mediator. However, if this is to be realized in a wider perspective, the EU will have to become better at bringing politics and policies together, meaning "the interplay between the EU's capacity to act as an external mediator and the conditionality of its policies" (Morillas, 2015: 33). In the case of Iran the EU's abilities at bringing these dimensions together do, despite a lack of consensus among its member states concerning the sanctions, seem to be somewhat improved.

The analysis of Iran's role in the Levant and the Gulf security subcomplexes indicated that Iran for decades was a relatively strong actor in both environments and that the sanctions only to some extent were important in determining the limits for Iranian policies there. In the Levant, Iran was pursuing its foreign policy goals via its alliances with Syria and Hezbollah (and to a lesser degree Hamas), whereas in the Gulf, Iran had to be more selfreliant. Economic constraints set limits for Iranian actions, as did the actions by the international sanctioning states and their alliances in the Middle East. But in the last years things tended to change, as demonstrated in several ways. When in the Levant context the EU, for instance, put the military wing of Hezbollah on its terror list, this only to a limited degree had any relation to the sanctions issue, but still indirectly played a role for the negotiating strength of Iran. The arms embargo and the economic effects of the sanctions over time weakened Iran vis-à-vis the Arab Gulf states, which, as part of the ongoing Gulf rivalry, purchased significant amounts of sophisticated weapons.

Summing up in regard to the hypothesis brought forward in the analytical framework section, it seems that the sanctions actually contributed to making Iran change its policies and agree to the JCPOA, thereby-as mentioned-practicing recombinant authoritarianism. In addition to that the EU was successful in bringing together a strong coalition of international powers behind the demands raised at the negotiating table. And furthermore: in general the sanctions weakened the position of Iran within the two regional security subcomplexes, in which it sought (and seeks) influence, in particular in the Gulf. Regarding the Levant subcomplex things are more complicated. As shown the historical dimension is important for the understanding of the complex developments of the EU-Iran relations, especially when it comes to the question of Syria. As pointed out the Iranians probably considered the emerging crisis in Syria in the first years after 2011 and Iran's support for the Syrian regime as constituting an obstacle for improving their relations with the EU. However, the arrival of the IS on the political and military scene of the IS added to the complexity and ambiguity. The EU and Iran have, as mentioned, common interests in controlling and rolling back the IS. In connection with that the Iranian decision, beyond the agreement on the JCPOA, to continue its support for the regime in Damascus might not be that important anymore, as seen from Brussels. 


\section{Notes}

1 The author is grateful for the inspiration from talks and publications, which came out of meetings arranged by the EUISS Taskforce in 2015, focusing on EU sanctions on Iran, Russia and Syria. See Dreyer et al.: On target? EU sanctions as security policy tools (Dreyer and Luengo-Cabrera, 2015).

2 This is based on interview by the author with Patrick Renaud, former Head of the European Union Delegation in Lebanon and Amman.

3 For a thorough presentation and analysis of the nuclear deal, see Gary Samore et al. (2015) The Iran Nuclear Deal. A Definitive Guide, The Iran Project. Belfer Center for Science and International Affairs, Harvard Kennedy School.

4 Interview by the author with anonymous Middle East EU-delegates.

5 By low-cost production is meant traditional production of oil and gas-in contrast to, for instance, shale oil extraction and other expensive types of oil and gas production.

\section{References}

Albright D, Hof F, LeBaron R and Cordesman A (2014) The United States, its Middle East allies and Iran: What is the way forward? Middle East Policy; 21 (1): $1-28$.

Alcaro R and Tabrizi AB (2014) Europe and Iran's nuclear issue: The labours and sorrows of a supporting actor. The International Spectator; 49 (3): 14-20.

Baldwin D (1999/2000) The sanctions debate and the logic of choice. International Security; 24 (3): 80-107.

Bazoobandi S (2015) Sanctions against Iran: Winners and losers. In: Dreyer I and Luengo-Cabrera J (eds). On target? EU sanctions as security policy tools. European Union Institute for Security Studies: Brussels, Belgium, pp 57-66.

Bergeijk P (2015) Sanctions against Iran-A preliminary economic assessment. In: Dreyer I and Luengo-Cabrera J (eds). On target? EU sanctions as security policy tools. European Union Institute for Security Studies: Brussels, Belgium, pp 49-56.

Buzan B and Wæver O (2003) Regions and Powers: The Structure of International Security. Cambridge University Press: New York.

Buzan B, Wæver O and de Wilde J (1998) Security: A New Framework for Analysis. Lynne Rienner Publications: Boulder, CO.

Chesterman S and Pouligny B (2003) Are sanctions meant to work? The politics and implementing sanctions through the United Nations. Global Governance; 9 (4): $503-518$

Dreyer I, Giumelli F, Luengo-Cabrera J, Portela C (2015) Conclusions. In: Dreyer I and Luengo-Cabrera J (eds). On target? EU sanctions as security policy tools. European Union Institute for Security Studies: Brussels, Belgium, pp 75-84.

Dreyer I and Luengo-Cabrera J (eds) (2015) On target? EU sanctions as security policy tools. European Union Institute for Security Studies: Brussels, Belgium, pp 75-84.

Drezner D W (2000) Bargaining, enforcement, and multilateral sanctions: When is cooperation counterproductive? International Organization; 54 (1): $73-102$.

EEAS. (2015) Eu Restrictive Measures in Force, Iran. European Commission: Brussels, Belgium, http://eeas.europa.eu/cfsp/sanctions/docs/measures_en.pdf.

Ehteshami A, Hinnebusch R, Huuhtanen H, Raunio P, Warnaar M, Zintl T (2013) Authoritarian Resilience and International Linkages in Iran and Syria. In: Heydemann S and Leenders R (eds). Middle East Authoritarianisms. Governance, Contestation, and Regime Resilience in Syria and Iran. Stanford University Press: Stanford, CA, pp 220-242.

Elliott K A (1998) The sanctions glass: Half full or completely empty. International Security; 23 (1): 50-65

EurActiv. (2013) EU adds Hezbollah's Military Wing to its Terrorist List, 22 July, http://www.euractiv.com/section/justice-home-affairs/news/eu-adds-hezbollahs-military-wing-to-its-terrorist-list/, accessed 1 June 2016.

Fakhoury T (2014) The EU and Lebanon in the wake of the Arab Uprisings. Middle East Policy; 21 (1): 133-143.

Friedman T (2015) Obama Makes His Case on Iran Nuclear Deal. New York Times, 14 July.

Gary Samore et al (2015) The Iran Nuclear Deal. A Definitive Guide, Belfer Center for Science and International Affairs, Harvard Kennedy School, http:// belfercenter.org/IranDealGuide, accessed 1 June 2016.

Giumelli F and Ivan P (2013) The effectiveness of EU sanctions. An analysis of Iran, Belarus, Syria and Myanmar (Burma). European Policy Centre: Brussels, Belgium, http://www.epc.eu/pub_details.php?pub_id $=3928$

Helfont S and Tally H (2012) Jordan: Between the Arab Spring and the Gulf Cooperation CouncilOrbis; 56 (1): 82-95.

Heydemann S and Leenders R (2011) Authoritarian learning and authoritarian resilience: regime responses to the 'arab awakening'. Globalizations; 8 (5): 647-653.

Heydemann S and Leenders R (2013) Middle East Authoritarianisms. Governance, Contestation, and Regime Resilience in Syria and Iran. Stanford University Press: Stanford, CA.
JCPOA. (2015) Joint Comprehensive Plan of Action. Vienna: The E3/EU+3 (China, France, Germany, the Russian Federation, the United Kingdom, the United States with the High Representative of the European Union and the Islamic Republic of Iran), http://eeas.europa.eu/statements-eeas/docs/iran agreement/iran_joint-comprehensive-plan-of-action_en.pdf, accessed 1 June 2016.

Juneau T (2014) Iran under Rouhani: Still alone in the world. Middle East Policy; 21 (4): 92-104.

Katzman K (2015) Iran Sanctions. Congressional Research Service Report, 7-5700. Washington DC, https://www.fas.org/sgp/crs/mideast/RS20871.pdf.

Khatib L (2015) Iran's Bad Bet. Tehran and Damascus After the Nuclear Deal. Foreign Affairs, Snapshot, 11 August.

Kienzle B (2012) Between Human Rights and Non-Proliferation: Norm Competition in the EU's Iran Policy. UNISCI Discussion Papers 30, Madrid. https:// revistas.ucm.es/index.php/UNIS/article/viewFile/40712/39032.

Kostadinova V (2013) What is the Status of the EU-GCC Relationship? Gulf Research Center Gulf Papers, https://www.files.ethz.ch/isn/167338/EU-GCC_ 9227.pdf .pdf, accessed 1 June 2016.

Kozhanov N A (2011) U.S. economic sanctions against Iran: Undermined by external factors. Middle East Policy; 18 (3): 144-160.

Maloney S (2015) Iran's Political Economy since the Revolution. Cambridge University Press: New York.

Miller J, Khoury N, Pillar P and Vakhshouri S (2015) Symposium: Iran and the Arab world: Implications of the nuclear negotiations. Middle East Policy; 22 (3): $1-26$

Mirbagheri F (2007) Narrowing the gap or camouflaging the divide: An Analysis of Mohammad Khatami's 'dialogue of civilisations'. British Journal of Middle Eastern Studies; 34 (3): 305-316.

Mogherini F (2015) The European Union in a Changing Global Environment. A More Connected, Contested and Complex World. European Commisison Brussels, Belgium, http://eeas.europa.eu/docs/strategic_review/eu-strategic review strategic review en.pdf.

Mohseni $\mathrm{P}$ et al (2015) Iran and the Arab World after the Nuclear Deal. Rivalry and Engagement in a New Era. Belfer Center for Science and International Affairs, Harvard Kennedy School: Massachusetts, http://belfercenter.org/theiranproject.

Monshipouri M and Dorraj M (2013) Iran's foreign policy: A shifting strategic landscape. Middle East Policy; 20 (4): 133-147.

Moret E (2015) Humanitarian impacts of economic sanctions on Iran and Syria. European Security; 24 (1): 120-140.

Morillas P (2015) From policies to politics: The European Union as a an international mediator in the mediterranean. PAPERSIEMed.; $\mathbf{2 3}$ 1-33, http://www.iemed.org/publicacions-en/historic-de-publicacions/paper siemed-euromesco/23.-from-policies-to-politics-the-european-union-as-aninternational-mediator-in-the-mediterranean.

Onderco M (2015) Money can't buy you love: The European Union member states and Iranian nuclear programme 2002-2009. European Security; 24 (1): 56-76.

Oskarsson K (2012) Economic sanctions on authoritarian states: Lessons learned. Middle East Policy; 19 (4): 88-102.

Pape R (1998) Why economic sanctions still Do No work. International Security; 23 (1): 66-77.

Patterson R (2013) EU sanctions on Iran: The European political context. Middle East Policy; 20 (1): 135-146.

Pollack K (2004) The Persian Puzzle. The Conflict Between Iran and America. Random House: New York.

Portela C (2010) European Union Sanctions and Foreign Policy. When and why do they work? Routledge: London and New York.

Portela C (2015) EU strategies to tackle the Iranian and North Korean Nuclear issues. In: Blavoukos DBS and Portela $\mathrm{C}$ (eds). The EU and the NonProliferation of Nuclear Weapons. Strategies, Policies, Actions. Palgrave Macmillan: New York.

Portela C and Ruffa C (2015) The Politics of Coercion: Assessing the EU's Use of Military and Economic Instruments. In: Jørgensen KE, Aarstad AK, Drieskens E, Laatikainen K and Tonra B (eds). The SAGE Handbook of European Foreign Policy, Vol. I-II. Sage: London, pp 543-556.

Seeberg P (2009) The EU as a realist actor in normative clothes: EU democracy promotion in Lebanon and the European Neighbourhood Policy. Democratization; 16 (1): 81-99.

Seeberg P (2015) The EU and the Syrian crisis: The use of sanctions and the regime's strategy for survival. Mediterranean Politics; 20 (1): 18-35.

Terrill W A (2015) Iran's strategy for saving asad. Middle East Journal; 69 (2) $222-236$.

Thomas A (2013) "Pariah states" and sanctions: The case of Syria. Middle East Policy; 20 (3): 27-40.

Tichý L and Odintsov N (2016) Can Iran reduce EU dependence on Russian Gas? Middle East Policy; 23 (1): 110-124

UN. (2006) Resolution 1696. United Nations Security Council: New York. 
UN. (2008) Resolution 1803. United Nations Security Council: New York.

UN. (2015a) Explanation of Vote at a UN Security Council Vote on Resolution 2231 on Iran Non-proliferation. U.S. Permanent Representative to the United Nations, Samantha Power. New York: United Nations Security Council, http:// usun.state.gov/remarks/6765.

UN. (2015b) Resolution 2131. United Nations Security Council: New York.

Van de Graaf T (2013) The "oil weapon" reversed? Sanctions against Iran and U.S.EU structural power. Middle East Policy; 20 (3): 145-163.

Waltz K (2012) Why Iran should get the bomb. Nuclear Balancing would mean stability. Foreign Affairs; 91 (4): 2-5.

\section{Data availability}

Data availability not applicable to this article as no datasets were generated or analysed.
Reprints and permission information is available at http://www.palgrave-journals.com/ pal/authors/rights_and_permissions.html

How to cite this article: Seeberg P (2016) The EU and the international sanctions against Iran: European and Iranian foreign and security policy interests, and a changing Middle East. Palgrave Communications. 2:16080 doi: 10.1057/palcomms.2016.80.

(c) This work is licensed under a Creative Commons Attribution 4.0 International License. The images or other third party material in this article are included in the article's Creative Commons license, unless indicated otherwise in the credit line; if the material is not included under the Creative Commons license, users will need to obtain permission from the license holder to reproduce the material. To view a copy of this license, visit http://creativecommons.org/licenses/by/4.0/

\section{Additional information}

Competing interests: The Authors declare no competing financial interests. 